\title{
The risk of sanctions following visits by monitoring bodies; a study conducted in Albania and Honduras
}

\author{
Marie Brasholt', Brenda van den Bergh', Erinda Bllaca 2, Alba Mejía 3, Marie \\ My Warborg Larsen', Anne Katrine Graudal Levinsen' ${ }^{1}$ and Jens Modvig'
}

Key points of interest

- Monitoring places of detention is an important way of preventing torture.

- In this study from Albania and Honduras, prisoners reported actions prior to a monitoring visit like painting, cleaning and transfers, feeling pressured to act in specific ways during the visit, and experiencing threats, humiliations and physical violence following monitoring visits.

- The study concludes that there is a need to further improve monitoring methodology to avoid reprisals.

\section{Abstract}

Introduction: Independent monitoring of places of detention is considered an effective way of preventing torture, but some reports have shown that detainees may face reprisals after engaging with monitors. This pilot study

1) DIGNITY - Danish Institute Against Torture, Denmark Correspondence to: mbr@dignity.dk

2) Albanian Rehabilitation Center for Trauma and Torture (ARCT), Albania Correspondence to: ebllaca@yahoo.com

3) Centro de Prevención, Tratamiento y Rehabilitación de Víctimas de la Tortura (CPTRT), Honduras

Correspondence to: cptrt@cablecolor.hn aims to further investigate the nature and the extent of such reprisals.

Methods: A cross-sectional survey among male prisoners in 4 prisons in Albania and 4 in Honduras was carried out using an interviewer-administered, structured questionnaire and collecting additional narrative comments. Strict ethical guidelines were followed, and follow-up visits took place to detect any sanctions following participation in the study.

Results: 170 detainees were invited to participate of whom 164 accepted. Most were aware of monitoring visits and found them helpful. More than one-third reported that authorities had made special arrangements like cleaning and painting prior to the monitoring visits, and $34 \%$ of participants in Albania and $12 \%$ in Honduras had felt pressured to act in a specific way towards the monitors. Onefifth had experienced sanctions after the last monitoring visit, most often threats and humiliations. During the follow-up visits, the interviewees reported no incidents following their participation in the study.

Discussion: This pilot study has shown that it is possible to collect information about detainees' experience with monitoring visits through interviews while they are still detained. The fact that reprisals are reported prior to and following monitoring visits points to the need of improving monitoring methodology to further lower the risk. Further research is needed to 
better understand the dynamics of the sanctions taking place with the aim of reaching a deeper understanding of potential preventive measures.

Keywords: Reprisals, sanctions, prison, monitoring, Albania, Honduras

\section{Introduction}

Torture and ill-treatment most often take place in places where people are deprived of their liberty. Such places are largely inaccessible to public scrutiny. Independent monitoring of places of detention is considered one of the most effective ways of combating torture and ill-treatment. This was the rationale for the adoption of the Optional Protocol to the United Nations Convention Against Torture (OPCAT) in December 2002 that has as its objective to establish a system of regular visits by independent national and international bodies to places of detention. At the international level, the task of monitoring is assigned to the Subcommittee on Prevention of Torture (SPT), and at the time of writing, 65 countries worldwide have designated their National Preventive Mechanism (NPM) in accordance with the protocol (OHCHR, n.d.). The preventive monitoring visits carried out by the NPMs should lead to reports and concrete recommendations on how to improve the protection of persons deprived of liberty ("detainees"). A recent research based on 16 country-examples has shown that domestic monitoring practices were correlated with a positive impact on the incidence of torture (Carver \& Handley, 2016).

During monitoring visits, external monitors typically interact with the detainees through interviews, meetings, and visits to wards, dormitories, workshops and other places where the detainees spend time. This enables the monitors to get a broad picture of the situation in the place visited and to triangulate the information they obtain with what they learn from other sources such as interviews with prison staff and review of documentation. However, it comes at the price of potentially exposing informants and other detainees to subsequent risks.

Reports exist that indicate that monitoring visits in some contexts may be associated with a risk of reprisals or sanctions for the prisoners who are in contact with the monitoring team. One such report indicated that prisoners were threatened by the authorities prior to the visits and that prisoners who complained about ill-treatment were physically punished for it afterwards (Amnesty International, 2008). It has also been reported that reprisals in connection with monitoring visits occur in different kinds of establishments, such as in police detention, prisons and psychiatric establishments, and intimidation and reprisals have been reported in a number of different countries (Armenia, Azerbaijan, Bulgaria, Greece, Hungary, the Republic of Moldova, the Russian Federation, Spain, "the former Yugoslavic Republic of Macedonia" and Ukraine) (CPT, 2015).

The Association for the Prevention of Torture has published a document that includes a description of different reprisals that might occur and guidelines on how to prevent these from happening (APT, 2012), but to our knowledge, no scientific studies about reprisals following monitoring visits documenting their nature and extent have so far been undertaken and published.

DIGNITY (Danish Institute against Torture) works with partners in different countries to treat survivors of torture and to prevent torture from happening in the first place. The latter includes being a member of the Danish NPM. Some of DIGNITY's international partners have access to places of detention and have a long track record of working 
inside these institutions which puts them in a unique position to study issues related to monitoring. Therefore, DIGNITY initiated a pilot study on reprisals in collaboration with two partner organizations, Albanian Rehabilitation Center for Trauma and Torture (ARCT, Albania) and Centro de Prevención, Tratamiento y Rehabilitación de Víctimas de la Tortura (CPTRT, Honduras). These partner organizations were selected based on their access to visit prisons, their capacity to interview prisoners and handle scientific data collection, and their motivation for collaboration and for mutual capacity building on research methods. Also, in the two selected countries, monitoring mechanisms exist and information is available about their activities.

Albania and Honduras ratified OPCAT in 2003 and 2006 respectively (OHCHR, n.d.), and both countries have designated their NPM. If visits from these NPMs have led to reprisals or sanctions for the prisoners, it has not been documented in either country. Some basic information about the countries and the prison setting is presented in table 1 .

\section{Research aim and objectives}

This study contributes to the knowledge and awareness about the conditions and treatments faced by detainees prior to and following visits from monitoring mechanisms. The immediate aim is to assess the extent to which detainees are coerced into giving certain information to the monitoring bodies, and whether they experience any kinds of retaliations from prison staff or fellow prisoners following monitoring visits.

\section{Methods}

The study results included both quantitative and qualitative data. A cross-sectional survey among detainees was carried out using an interviewer-administered, structured question- naire. In addition, narrative comments from the interviewees were taken for each question. The data collection took place in December 2015.

In Honduras, four prisons (in San Pedro Sula, Santa Bárbara, Danlí, and Comayagua) were selected by CPTRT based on three criteria: 1) access to visit the prison, 2) population quantity in each prison, and 3) ability to conduct 20 interviews in each prison center. In Albania, four prisons (in Fieri, Shën Kolli, Rrogozhina, and Peqini) were selected by ARCT based on four criteria: 1) capacity of accommodation, 2) sufficient level of security for interviewers, 3) highest number of life sentenced prisoners, and 4) mixed detained population (normal/high security, pre-trial/ sentenced). Characteristics of the prisons are presented in table 2 .

\section{Data collection}

Data was collected through interviews structured by a questionnaire administrated by staff from ARCT and CPTRT. In Albania, the same group of four interviewers visited all four prisons consecutively, whereas in Honduras distinct teams of two interviewers visited the four prisons on the same day. All interviews were conducted in the participants' own language and they took place on the prison premises. The local prison authorities helped identify suitable locations for the interviews, so they could be conducted in privacy. The interviewers conducted a second visit to the prisons a few days after the interviews had been conducted to monitor the continued well-being of the detainees who had been interviewed.

Each interviewer answered 7 questions by the end of the data collection, assessing the selection process, the prisoners' understanding of the questions, the follow-up visits and if there had been any other contact between 
Table 1. Country and prison background information

\begin{tabular}{lll}
\hline Country & Albania & Honduras \\
\hline Human & 0.733 & 0.606 \\
Development & & \\
Index & & \\
(UNDP, n.d.) & & \\
\hline
\end{tabular}

Torture and ill-treatment
Absence of comprehensive and disaggregated data on complaints, investigations, prosecutions and convictions of cases of torture and ill-treatment. Reports of high numbers of torture and ill-treatment during pretrial detention. Alleged victims not aware of complaint procedures, and some are afraid of counter-complaints and reprisals. Hardly any allegations of physical ill-treatment of prisoners by staff were received in any of the prisons visited by CPT in 2017 (OHCHR, 2012; UNHCR, 2018).

Prison conditions Physical conditions in some prisons largely satisfactory, whereas in others, conditions are poor with cells being severely overcrowded, damp and with lack of adequate ventilation and natural light.

253 complaints of torture to the Office of the Special Prosecutor for Human Rights between 2009 and 2014, 912 complaints of torture and ill-treatment to the Office of the National Commissioner for Human Rights between 2010 and 2014. Several additional cases of torture and ill-treatment documented and reported by NGOs (OHCHR, 2010; OHCHR, 2016).

153 violent deaths in the prison system from Jan. 2009 to June 2014, of these 81 in the San Pedro Sula prison. Prisons substandard and characterized by overcrowding, lack of proper hygiene, ventilation and sanitation. Lack of adequate staff. In-mate self-rule through socalled coordinadores and loss of control by prison authorities resulting in corruption, violence, traffic in prohibited substances, and informal markets of many kinds.

Prison population Rate: 180 per 100.000

('Albania | World Prison population: 5,152

Prison Brief', 2019; Pre-trial detainees: $41 \%$

'Honduras | World Average occupancy: $103.8 \%$

Prison Brief', 2019)

\begin{tabular}{ll}
\hline Categories of & 8 high security prisons \\
prisons $^{1}$ & 2 normal security prisons \\
& 4 specialized prisons (women, disabled \\
& and other special groups) \\
& 8 pre-trial detentions
\end{tabular}

Rate: 229 per 100.000

Prison population: 20,506

Pre-trial detainees: $53.1 \%$

Average occupancy: $193.5 \%$
2 high security prisons

25 normal security prisons

4 specialized prisons (women and minors) 
Table 2. Prisons characteristics

\begin{tabular}{|c|c|c|c|}
\hline Prison & Type & $\begin{array}{l}\text { Actual number of } \\
\text { detainees/capacity } \\
\text { (occupancy rate) }^{1}\end{array}$ & $\begin{array}{l}\text { Additional } \\
\text { comments }\end{array}$ \\
\hline $\begin{array}{l}\text { Shën Kolli, } \\
\text { Albania }\end{array}$ & $\begin{array}{l}\text { Normal and high security, } \\
\text { pre-trial detention, and youth }\end{array}$ & $\begin{array}{l}790-870 / 700 \\
(113-124 \%)\end{array}$ & \\
\hline $\begin{array}{l}\text { Rrogozhina, } \\
\text { Albania }\end{array}$ & $\begin{array}{l}\text { Normal security and pre-trial } \\
\text { detention }\end{array}$ & $\begin{array}{l}418-485 / 343 \\
(122-141 \%)\end{array}$ & $\begin{array}{l}\text { A fire in } 2015 \\
\text { destroyed a section of } \\
\text { the prison }\end{array}$ \\
\hline Peqini, Albania & $\begin{array}{l}\text { Normal and high security, } \\
\text { life-sentence, and pre-trial } \\
\text { detention }\end{array}$ & $\begin{array}{l}788-811 / 685 \\
(118 \%)\end{array}$ & \\
\hline Fieri, Albania & $\begin{array}{l}\text { Normal security and pre-trial } \\
\text { detention }\end{array}$ & $\begin{array}{l}870 / 780 \\
(112 \%)\end{array}$ & $\begin{array}{l}\text { New institution in } \\
\text { function since } 2014 \\
\text { housing detainees from } \\
\text { Jordan Misja Prison }\end{array}$ \\
\hline $\begin{array}{l}\text { Danlí, } \\
\text { Honduras }\end{array}$ & Normal security & $\begin{array}{l}704 / 204 \\
(345 \%)\end{array}$ & \\
\hline $\begin{array}{l}\text { Comayagua, } \\
\text { Honduras }\end{array}$ & $\begin{array}{l}\text { Previously known as } \\
\text { penitentiary farm, maintains } \\
\text { some farming activities }\end{array}$ & $\begin{array}{l}616 / 587 \\
(105 \%)\end{array}$ & $\begin{array}{l}\text { A fire in } 2012 \text { led } \\
\text { to the death of } 362 \\
\text { detainees }\end{array}$ \\
\hline $\begin{array}{l}\text { Santa Barbara, } \\
\text { Honduras }\end{array}$ & Normal Security & $\begin{array}{l}439 / 200 \\
(220 \%)\end{array}$ & \\
\hline $\begin{array}{l}\text { San Pedro Sula, } \\
\text { Honduras }\end{array}$ & Normal Security & $\begin{array}{l}2983 / 800-900 \\
(331-373 \%)\end{array}$ & $\begin{array}{l}3 \text { detainees killed and } \\
32 \text { hurt during prison } \\
\text { riot in } 2015\end{array}$ \\
\hline
\end{tabular}

1 Information provided by ARCT and CPTRT

the interviewers and the prisoners after the interviews had taken place.

Both research partners provided a written report to DIGNITY with background information about the prisons and the data collection process.

\section{Questionnaire}

The questionnaire consisted of 19 questions and was developed in English before it was translated into Albanian and Spanish by ARCT and CPTRT. The study participants were encouraged to provide narrative comments to the problems raised in the structured interview, and short versions of these were written down by the interviewers. No part of the questionnaire contained personal information beyond name of prison and length of stay.

\section{Study participants and sampling procedures}

170 male prisoners were invited to participate in the study. Of these, six eventually did not participate resulting in a study population of 164 prisoners (participation rate: $96.5 \%$ ), 79 
in Albania and 85 in Honduras. 150 study participants $(93.8 \%)$ were selected randomly for the interviews, while 10 (6.3\%) were selected by their personal requests to take part in the study (missing data on selection process: 4 ). The randomization technique used differed from prison to prison. In Albania, prisoners were randomly selected by the interviewers, and a few of the prisoners also participated in another survey made by ARCT at the same time. In Danlí the interviewers chose specific areas in the prison and let those participate who wanted to. In Comayagua they chose two prisoners from 10 different households in the prison. In Santa Barbara they chose participants at random. In San Pedro Sula the participants were chosen at random by calling them out. If they did not want to participate, a substitute was chosen straight away. They did not use lists to choose participants, and all were chosen on the same day.

The interviewers identified language barriers in two of the interviews $(1.2 \%)$ and other difficulties in nine interviews including the respondents being fearful that reprisals might take place and some respondents having difficulties understanding some of the questions due to low educational levels $(5.5 \%)$. Where a language barrier or other issues hindered understanding of a question, the answer to the question was recorded as either "missing" or "don't know" depending on the response given.

\section{Data handling and analysis}

After data collection, the data was uploaded to "SurveyXact", a data management program which allows for legality checks during input. Data was afterwards transferred to SPSS v.25 for analysis.

Only descriptive statistics were used since numbers were too small to allow for comparative analyses.

\section{Ethical considerations}

\section{Ethical review}

During the study it was ensured that the dignity, rights, and well-being of the research participants and the researchers involved were respected. The principles such as those detailed in the Helsinki Declaration concerning the Ethical Principles for Medical Research involving Human Subjects were adhered to (WMA, 2013). The following principles for data protection, anonymity, confidentiality and privacy were followed:

- Research partners were trained on the aim of the study and the data collection process.

- The interviewers were trained to be sensitive to individual, cultural and role differences.

- Participants were asked for informed consent at the start of the interview.

- The interviewers informed the participants:

- About the aim and methodology of the study

- About the intended use of the data

- That they had the opportunity to ask questions about the research at any time

- That their participation was voluntary

- That they had the right to decline participation or withdraw from the study at any time

- That, in the event of withdrawal, all their data would be deleted and removed from the study

- That no person-attributable data would be collected and reported

- The participants did not receive any incentives for their participation

- Interviews took place in a private setting

- Referral was to be considered if a prisoner reported torture or other traumatization and was in urgent need of support or treatment 
- All data was stored in SurveyXact anonymously $^{1}$ and remained confidential. The analysis of the data focused on general results and not on individual replies.

The research underwent internal ethical review according to requirements applying at DIGNITY. Since the collected data was non-attributable, the research was not subject to ethical review in Denmark by the Danish national ethical committee system, nor was permission from the Data Inspection Authority required. Ethical review was also not needed in Albania or Honduras for this type of study, and at the time of the study no ethical committee existed in the two countries.

\section{Prisoner safety}

A key ethical challenge was to ensure the safety of the prisoners who participated in the interviews, since they could become victims of sanctions on the part of prison personnel or fellow prisoners for providing information to the interviewer. Different measures were taken to counter this risk.

ARCT and CPTRT informed national prison authorities about the study prior to initiating the interviews and stressed that it was their obligation to ensure that those participating in the study were protected against sanctions following their participation.

As the research partners access the prisons in their country on a regular basis, they are used to continually monitor and evaluate prisoner safety and risks. For this study, the researchers also conducted a short, announced follow-up visit to each prison a few days after the interviews had taken place, to ensure the

1 In Albania, many prisoners insisted on signing the filled-out questionnaire after their interview. This signature was not coded during data entry. well-being of the participants. Participants were encouraged to contact the interviewing organizations by phone, either personally or via family, in case they experienced any negative consequences after their participation in the study.

Each participant was interviewed in a private environment, meaning that the conversation could not be overheard or overseen by members of the prison staff or by fellow prisoners. Information about the prisoners' length of stay in the prison was collected, but not any information about their identity or reason for imprisonment.

A risk existed that participants might not dare to inform about reprisals at the follow-up visit for fear of further sanctions. During follow-up visits, interviewers were therefore particularly observant to any signs that physical reprisals or other sanctions had taken place or that information was withheld. Had strong suspicions arisen, instructions had been given to the interviewers to report to the prison authorities in order for them to protect the prisoner, e.g. through transfer to another place of detention.

\section{Informed consent}

Prior to giving consent, the study participants were informed as stated above. The interviewers also specifically made the participants aware that they could not completely exclude the risk of sanctions or negative consequences after participation. Informed consent was collected at the outset of the interview. To maintain anonymity, the consent was given only orally and documented in the questionnaire.

\section{Results}

The interviews and follow-up visits were conducted without any major problems or incidents, and no negative consequences of the study were discovered during or after the data 
collection period. There were also no suspicions that participants withheld information during the follow-up visits.

\section{Descriptive statistics}

A total of 164 interviews were conducted: 79 in Albania and 85 in Honduras. There were between 19 and 23 study participants in each of the eight prisons (table 3 ). They had spent an average of 50-63 months in prison.

Of the 164 study participants, 160 were aware that monitoring visits had taken place to the prison during their detention (table 3 ). Details like who had undertaken specific visits (e.g. NGOs, judges, national preventive mech- anisms etc.) were not collected. 110 participants (72 in Albania and 38 in Honduras) had interacted directly with monitors during the last monitoring visit that they were aware of, whereas the others had only heard about it or seen the monitors pass by (table 3).

Prisoners'perception of visits by independent monitors and the impact thereof

$87.2 \%$ of the study participants found it important or very important that independent monitors visit prisons whereas only $9.1 \%$ found it not so important or not important at all (table 4).

Table 3. Prisoner characteristics, awareness of monitoring visits, and interaction with monitors

\begin{tabular}{|c|c|c|c|c|c|}
\hline Country & Prison & $\begin{array}{l}\text { Prisoers } \\
\text { inter- } \\
\text { viewed, } \mathrm{n} \\
(\%)\end{array}$ & $\begin{array}{l}\text { Time spent } \\
\text { in prison, } \\
\text { months }^{1} \\
\text { Median } \\
(\min -\max )\end{array}$ & $\begin{array}{l}\text { Numbers } \\
\text { of prison- } \\
\text { ers aware of } \\
\text { monitoring } \\
\text { visits, } n(\%)\end{array}$ & $\begin{array}{l}\text { Prisoners who } \\
\text { had interacted di- } \\
\text { rectly with mon- } \\
\text { itors during the } \\
\text { last monitoring } \\
\text { visit, } n(\%)\end{array}$ \\
\hline \multirow[t]{5}{*}{ Albania } & Jordan & $20(25.3)$ & $\begin{array}{ll}42 & \end{array}$ & $79(100.0)$ & $72(91.1)$ \\
\hline & Shen Kolli & $19(24.1)$ & & & \\
\hline & Rrogozhina & $20(25.3)$ & & & \\
\hline & Peqini & $20(25.3)$ & & & \\
\hline & Total & $79(100.0)$ & & & \\
\hline \multirow{6}{*}{$\begin{array}{l}\text { Hondu- } \\
\text { ras }\end{array}$} & San Pedro & $21(24.7)$ & 44 & $81(95.3)$ & $38(46.9)$ \\
\hline & Sula & & $(1-216)$ & Missing $=4$ & Missing $=4$ \\
\hline & $\begin{array}{l}\text { Santa } \\
\text { Barbara }\end{array}$ & $21(24.7)$ & & & \\
\hline & Danlí & $20(23.5)$ & & & \\
\hline & Comayagua & $23(27.1)$ & & & \\
\hline & Total & $85(100.0)$ & & & \\
\hline
\end{tabular}

1 As time spent in prison does not follow a normal distribution, the median is reported in table 2. 
The main reasons indicated by the participants in both Albania and Honduras for the visits being important was that the monitors listen to them, are helpful, respect the rights of the detainees and give them advice. As was stated by one prisoner:

"Monitoring can help us raise the problems [...] nobody pays attention to our problems in this institution"2 (prisoner, Albania)

One interesting difference was that prisoners in Honduras also mentioned reasons such as showing humanity, change of staff behaviour, better treatment and less beatings, while such were not mentioned by the prisoners in Albania.

"The treatment in the prison has changed. Before there were no visits [...] and before the police beat quite a lot. It is not like that now when there are more visits from human rights ${ }^{3}$ " (prisoner, Honduras).

Those who did not find the visits important indicated that the visits are too few and that the monitors have no actual power.

In Honduras, the majority stated that the conditions in the prison improved following a

2 Translations of Albanian quotes into English done by ARCT staff

Table 4. Prisoners' thoughts about independent monitoring visits, $\mathrm{n}(\%)$

\begin{tabular}{lll}
\hline & Albania & Honduras \\
\hline Very important & $23(29.1)$ & $52(61.2)$ \\
Important & $43(54.4)$ & $25(29.4)$ \\
Not so important & $1(1.3)$ & $4(4.7)$ \\
Not important & $8(10.1)$ & $2(2.4)$ \\
at all & & \\
Don't know & $4(5.1)$ & $2(2.4)$
\end{tabular}

3 Translations of Spanish quotes into English done by DIGNITY staff monitoring visit, both when asked about the first few days after the visit and the long-term impact (55.5\%). 40.7\% stated that the conditions in the prison remained unchanged. In Albania, $29.1 \%$ of the participants stated that the conditions in the prison improved. $59.5 \%$ found that the conditions in the prison remained unchanged (table 5). Notably, of the six participants in Albania who said that conditions got worse, four came from the same prison.

Prisoners' reports of arrangements set in place by authorities to ensure that the monitoring team would get a positive impression of the prison conditions

$36.5 \%$ of the participants had experienced that the authorities had made special arrangement prior to a monitoring visit, with most cases in Honduras $(42.0 \%$ vs. $30.8 \%$ in Albania). Seven prisoners in Albania informed that the prison had been painted before the visits, and seven had experienced

Table 5. Prisoners' assessment of the last monitoring visit's impact. $\mathrm{N}=160, \mathrm{n}(\%)$

\begin{tabular}{lcc}
\hline & Albania & Honduras \\
\hline $\begin{array}{l}\text { Prison conditions } \\
\text { improved } \\
\text { considerably }\end{array}$ & $5(6.3)$ & $9(11.1)$ \\
$\begin{array}{l}\text { Prison conditions } \\
\text { improved }\end{array}$ & $18(22.8)$ & $36(44.4)$ \\
$\begin{array}{l}\text { Prison conditions } \\
\text { were unchanged }\end{array}$ & $47(59.5)$ & $33(40.7)$ \\
$\begin{array}{l}\text { Prison conditions } \\
\text { got worse }\end{array}$ & $6(7.6)$ & $1(1.2)$ \\
$\begin{array}{l}\text { Prison conditions } \\
\text { got considerably } \\
\text { worse }\end{array}$ & $1(1.3)$ & $1(1.2)$ \\
$\begin{array}{l}\text { Don't know } \\
\text { Pon }\end{array}$ & $2(2.5)$ & $1(1.2)$
\end{tabular}

that the prison was cleaned. Some also men- 
tioned that the showers were fixed, they got new mattresses, and recreational time was added, and three prisoners mentioned that the number of inmates per cell was changed to reduce overcrowding. It was also mentioned that prison staff had chosen certain inmates to interact with the monitors.

"The prison staff has selected five inmates to answer positively to monitors" (prisoner, Albania)

"They changed the number of inmates in a cell, we changed the floor to reduce the number of persons" (prisoner, Albania).

12 prisoners in Honduras informed that they were instructed to behave well, 7 were told to correct their clothes, and 6 mentioned that they had had to clean more than usual. 3 prisoners said they painted the place and 4 mentioned that they were forced to participate in a raffle about who should make improvements to the place. Some mentioned that they were forced to respond well when asked questions by the monitors and one told that the coordinators were hiding a detainee who had been beaten in an isolation cell.

"They do not let us get close to human rights, only the coordinators talk to them, sometimes there are people beaten in the bartolinas and the coordinators hide them" (prisoner, Honduras).

"Yes, the conditions of the prison were improved plus the side where the women are, paint, clean and fix the roof ... that is not done every day" (prisoner, Honduras).

Other arrangements set in place before a monitoring visit were improvements of inventory, change of number of prisoners per cell, change in the activities and instructions on how to look and behave.

"In this case, it was an activity in the classroom, and they were very well arranged, with the participation of doctors, coordinators and other technical personnel" (prisoner, Honduras).
Prisoners' reports of pressure to act in a specific way in connection with monitoring visits In Albania, $34.2 \%$ of the participants had felt pressured to act in a specific way during the last monitoring visit to ensure that the monitors in the last monitoring visit would get a positive impression whereas this was only the case for $12.3 \%$ of the participants in Honduras.

One prisoner from Albania explained that "the police officers come to make "controls" and letting us know that the monitoring is coming (like pressure)" (prisoner, Albania).

Another prisoner from Honduras explained that "sometimes (they) ask questions about how you feel in the penitentiary center in front of police, and one is forced to respond well" (prisoner, Honduras).

Other ways of being pressured mentioned in Honduras were threats of being transferred.

Sanctions from prison authorities, prison staff or other prisoners in relation to visits by independent monitors

$25.3 \%$ of the participants in Albania knew other prisoners who stated to have experienced sanctions or negative consequences after the last monitoring visit. In Honduras this was the case for $19.8 \% .20 .3 \%$ of participants in Albania and $22.2 \%$ in Honduras had experienced sanctions or negative consequences themselves. In both countries the

Table 6. Percentage of prisoners who felt pressured to act in a specific way during a monitoring visit, $\mathrm{N}=160, \mathrm{n}(\%)$

\begin{tabular}{lll}
\hline & Albania & Honduras \\
\hline $\begin{array}{l}\text { Threatened with } \\
\text { sanctions }\end{array}$ & $5(6.3)$ & $5(6.2)$ \\
$\begin{array}{l}\text { Promised extra } \\
\text { privileges }\end{array}$ & 13 & $0(0.0)$ \\
$\begin{array}{l}\text { Felt pressured in } \\
\text { another way }\end{array}$ & $7(8.9)$ & $4(4.9)$ \\
& &
\end{tabular}


Table 7. Prisoners' experience of sanctions or negative consequences after last monitoring visit, $\mathrm{N}=160, \mathrm{n}(\%)$

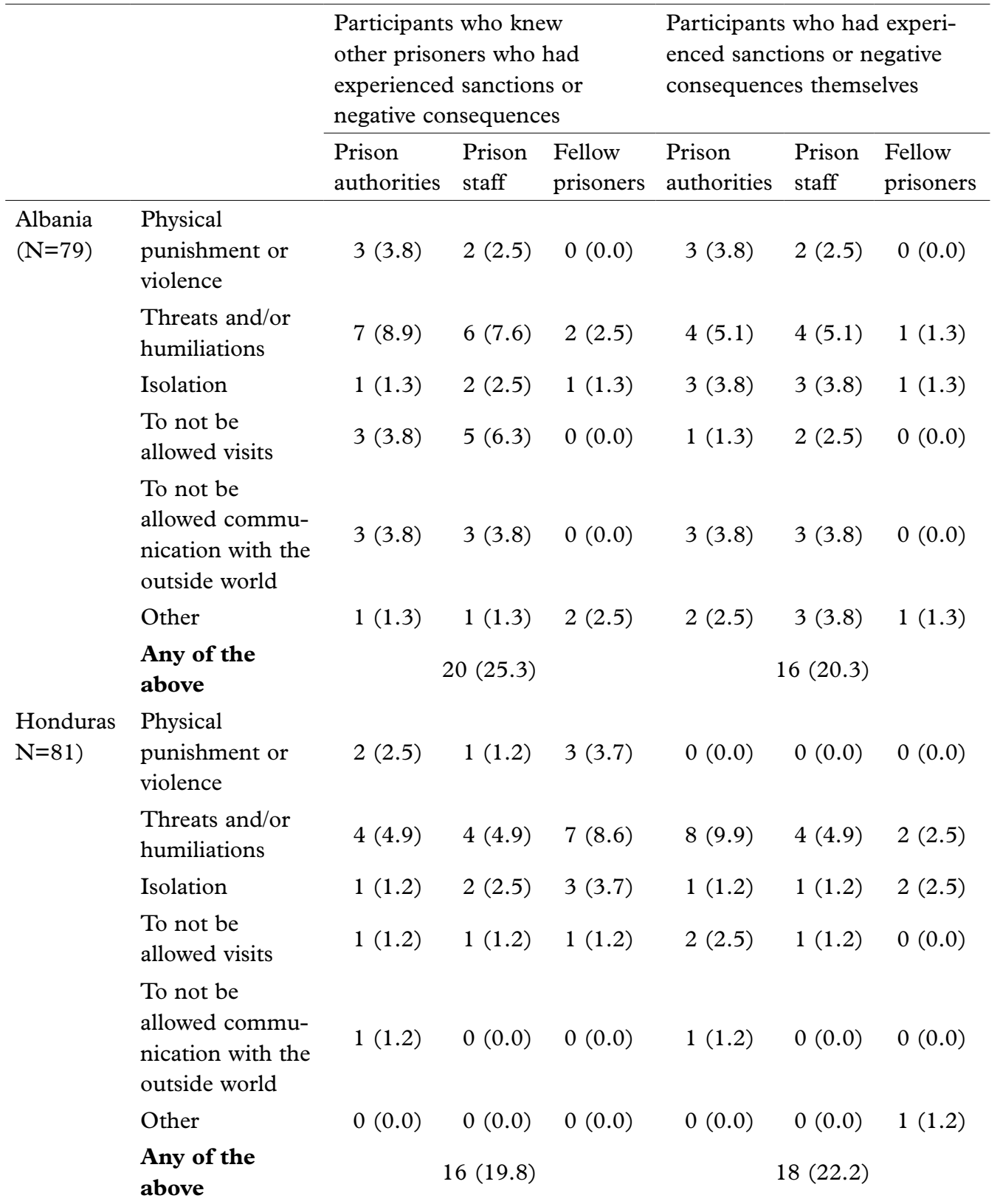

Note: Some prisoners reported more than one type of sanction or negative consequence 
most frequent sanction reported was threats and humiliations. Sanctions were reported from all eight prisons.

In Albania, the participants mentioned that other types of sanctions experienced by themselves or others included disciplinary measures and forced transfers. Seven mentioned that permissions were stopped, two mentioned isolation, and two mentioned pressure from authorities. In Honduras, other types of sanctions mentioned included intimidation, sanctions, and isolation. Six mentioned threats from coordinadores, two mentioned physical punishment, two mentioned electric shocks, and two mentioned physical abuse by the assistant nurse.

One participant even said: "the police wants to give arms to the coordinators so that they will kill the people that would be against the system that they have imposed by order of the authorities" (prisoner, Honduras).

The participants attributed several different reasons to the sanctions they had experienced after the last monitoring visit. In Albania, these included very concrete things like speaking about the telephones and communicating with family, but also talking about violations, talking with the ombudsman, complaints, criticizing the police staff and speaking negatively about prison conditions.

One participant said, "I spoke with the monitors about the telephones and the police staff dragged me and put me in isolation for three days" (prisoner, Albania).

In Honduras, the participants mentioned lack of respect for the rules, complaints, power conflicts, that the coordinators want to exercise control, and abuse of authority by the director.

\section{Reporting of sanctions}

Of those who had experienced sanctions, $40.5 \%$ of participants in Albania had reported their experiences of sanctions as compared to
$37 \%$ in Honduras. Prisoners in Albania most often reported to monitors but also to the court, the ombudsman, prison authorities and prison staff. In Honduras, prisoners most often reported to their families but also to the judge, lawyers, the national commissioner for human rights and the interviewer. No information was collected about the outcome of the reporting, but as a comment one participant noted that he would not pass on this type of information again because his name was afterwards put on a list that was passed on. Others stated that they did not know how to report sanctions.

\section{Discussion}

This study is a pilot study intended to test whether it is at all possible to collect information about detainees' experience with monitoring visits through interviews while they are still in prison. The fact that the study was carried out without any incidents shows that this is indeed possible if the interviewers have contextual knowledge and apply strict precautionary measures to avoid any potential harm to the informants. One might argue that what the study shows is that the researchers did not discover incidents that had happened nevertheless, but this is unlikely given that they already have close relations with the prisoners and are used to exchanging confidential information with them, gave the participants different avenues to report any incidents, and carried out follow-up visits. Whether similar studies can be applied in other contexts in the same way of course remains to be seen, but it is promising that it has been possible to conduct the study in two very different countries and in eight prisons.

It should be mentioned that not only prison management, but also higher prison authorities were made aware of the study and consequently may have been particularly observant to preventing harm. The follow-up 
visits were announced which may also have made authorities particularly keen to avoid reprisals. Additionally, the researchers were able to strictly adhere to confidentiality. In a monitoring context, the role of higher prison authorities and the monitors' ability to maintain confidence may be less clear.

The majority of the interviewees believed that monitoring visits are important, and many of them have actually experienced improvements in the prison conditions following a monitoring visit. This is an important finding. Equally important, however, is that some participants - particularly in Albania - report that prison conditions got worse after a monitoring visit. No specific information about this was collected, but it would be an important aspect to investigate further in future studies.

More than one-third of the participants reported that special arrangements had been made prior to a monitoring visit such as improving the material conditions and reducing overcrowding. This of course points to the importance of unannounced visits that would not make such arrangements possible and therefore may give the monitors a truer picture of the reality on the ground. What is also important is how the monitoring visit itself may in fact imply worsened conditions for those who may be forced to do work which they would otherwise not have had to do, and for those who are forcibly transferred.

Another way of affecting the monitoring team's assessment of the place is to pressure participants to respond in certain ways. This was reported by more than one-third of the Albanian interviewees and more than one out of ten in Honduras. There was an interesting difference here with the Albanian prisoners mostly being promised extra privileges, whereas in Honduras they would rather be threatened with sanctions. It is important that monitors understand the potential underlying dynamics of the answers they receive, including the different use of "sticks and carrots" in different contexts, and that they look for ways to get information about this during their interviews.

In both countries, about one-fifth of the participants reported having experienced sanctions after the last monitoring visit. This is a very high proportion and may be the most important finding of this study. In Albania, the sanctions included physical violence committed by prison staff and prison authorities, and in both countries prisoners experienced sanctions that may influence their psychological well-being, like isolation and a ban on visits and communication with the outside world. The fact that sanctions indeed do take place after monitoring visits and to such a high extent as reported in this study should be a wake-up call to all monitors to make sure that they always do their utmost to minimize the risk of sanctions.

In Honduras, a number of prisoners reported knowing others who had been subjected to sanctions by fellow prisoners, and five reported having experienced sanctions from others themselves. The numbers are very small, but the finding might be interpreted as a consequence of how the prison system is functioning in Honduras with very limited prison staff, gangs setting the agenda, and so-called coordinadores being appointed to ensure peace and order in the prison.

Finally, it is worth noticing that in both countries not only prison staff and fellow prisoners were involved in sanctions but also prison authorities. This points to the fact that reprisals may be a systemic problem and not only related to a few staff members who don't follow procedures or a few prisoners who dominate the prison environment.

\section{Limitations}

The countries and the prisons were purposefully chosen which introduces an obvious risk 
of selection bias. The fact that the prisons are in two different countries in two different continents and no obvious difference was found between prisons in each country in terms of participation rates may however be evidence that the chosen methodology is indeed feasible, even under very different circumstances.

The study aimed for random selection of participants, but this was obviously handled very differently, not only across countries but in the case of Honduras even across prisons within the same country. Also, the interviewers did not stick completely to the chosen selection procedure since they did not want to exclude prisoners who volunteered information to them. Needless to say, this issue should be handled more carefully in future studies.

Generally, the response rate in the study was high, but a few prisoners who were asked to participate in the study eventually did not. No information about these prisoners was collected, and it is therefore impossible to assess in which direction their responses might have drawn the results. In future studies, a more detailed non-responder analysis would be desirable.

There is always a risk of information bias in studies based on questionnaires, and this study is no exception to this. Prisons are institutions with high levels of social control, and the prisoners may not have wanted to divulge information for fear of subsequent negative consequences. This tendency to underreport may be even more pronounced if a participant had already experienced reprisals and sanctions following monitoring visits or even following participation in other scientific studies. On the other hand, participants with an interest in putting prison staff, prison administration or fellow prisoners in an unfavorable light, for example to be transferred to another insti- tution or to get revenge in case of a conflict, might tend to overreport.

Finally, recall bias may have influenced the interviewees' answers, and information may have been lost or compromised when more detailed answers were being recorded by the interviewers.

\section{Perspectives}

Despite its limitations, this study has resulted in some interesting findings that in the future may qualify the way in which findings during monitoring visits are interpreted and reprisals prior to and after monitoring visits are prevented.

As long as sanctions and reprisals are happening in relation to monitoring visits, which has been evidenced by this study, there is still work to be done for monitors to improve the way in which they perform their task. Monitors should continuously seek new ways of obtaining information that do not put prisoners in danger, all monitors should be trained on issues linked to reprisals, and local guidelines taking into account the exact risks known in the context should be developed and adhered to at all times.

Research has a role to play in improving the way monitors work. This study is a first step towards quantifying and better understanding reprisals in relation to monitoring. Similar research is needed in more contexts to assess the general validity of the results, and more research is needed to better understand the dynamics of the sanctions taking place with the aim of reaching a deeper understanding of potential preventive measures.

\section{Acknowledgements}

164 male prisoners in Albania and Honduras generously shared with us their views and experiences. They did so even though interaction with researchers might make them vul- 
nerable to sanctions following the interviews. We are immensely grateful that they decided to participate despite the potential risk. We are also grateful to prison authorities who facilitated the study by seeking ways to ensure the private interaction with the prisoners in overcrowded prison environments, and to the interviewers.

We are grateful to Denmark's Ministry of Foreign Affairs, Danish International Development Agency (DANIDA), for its financial support to this research.

\section{References}

Albania | World Prison Brief. (2019). https://www. prisonstudies.org/country/albania

Amnesty International. (2008). Mauritania: Torture at the heart of the state. https://www.refworld.org/ docid/49365b2026.html

APT. (2012). Mitigating the risks of Sanctions related to Detention Monitoring. Association for the Prevention of Torture. Geneva. https://www.apt. ch/content/files_res/Briefing4_en.pdf

Carver, R., \& Handley, L. (Eds.). (2016). Does torture prevention work? Liverpool: Liverpool University Press.

European Committee for the Prevention of Torture. (2015). 24th General Report of the CPT. Council of Europe.

Honduras | World Prison Brief. (2019). https://www. prisonstudies.org/country/honduras

OHCHR. (n.d.). National Preventive Mechanisms. https://www.ohchr.org/EN/HRBodies/OPCAT/ Pages/NationalPreventiveMechanisms.aspx

OHCHR. (2010, February 10). Report on the visit of the Subcommittee on Prevention of Torture and Other Cruel, Inhuman or Degrading Treatment or Punishment to Honduras. https://tbinternet.ohchr. org/_layouts/15/treatybodyexternal/Download.as px? symbolno $=\mathrm{CAT} \% 2 \mathrm{fOP} \% 2 \mathrm{fHND} \% 2 \mathrm{f} 1 \& \mathrm{Lan}$ $\mathrm{g}=\mathrm{en}$

OHCHR. (2012, June 7). Considerations of reports submitted by States parties under article 19 or the Convention-Concluding observations of the Committtee against Torture, Albania. https://tbinternet.ohchr.org/_layouts/15/ treatybodyexternal/Download.aspx?symbolno $=\mathrm{C}$ AT $\% 2 \mathrm{fC} \% 2 \mathrm{fALB} \% 2 \mathrm{fCO} \% 2 \mathrm{f} 2 \mathrm{\& Lang}=\mathrm{en}$

OHCHR. (2016, August 26). Concluding observations on the second periodic report of Honduras *. https://tbinternet.ohchr.org/_layouts/15/
treatybodyexternal/Download.aspx?symbolno=CA

T\% $\%$ fC $\% 2 \mathrm{fHND} \% 2 \mathrm{fCO} \% 2 \mathrm{f} 2 \& \mathrm{Lang}=\mathrm{en}$

UNDP. (n.d.). Human Development Reports:

Table 1. Human Development Index and its components. http://hdr.undp.org/en/composite/ HDI

UNHCR. (2018, May 24). Refworld | Report to the Albanian Government on the visit to Albania carried out by the European Committee for the Prevention of Torture and Inhuman or Degrading Treatment or Punishment (CPT). https://www.refworld.org/ docid/5b0681334.html

WMA. (2013). World Medical Association Declaration of Helsinki: Ethical Principles for Medical Research Involving Human Subjects. fAMA, 310(20), 2191. https://doi.org/10.1001/ jama.2013.281053 